Andrew M. Jefferson ${ }^{1}$

\title{
Therapeutic Discipline? Reflections on the penetration of sites of control by therapeutic discourse
}

"To give some assistance in wearing away certain self-evidences and commonplaces about madness, illness, crime and punishment; to bring it about, together with many others, that certain phrases can no longer be spoken so lightly, certain acts no longer, or at least no longer so unhesitatingly, performed; to contribute to changing certain things in people's ways of perceiving and doing things; to participate in this difficult displacement of forms of sensibility and thresholds of tolerance - I hardly feel capable of attempting much more than that."

(Michel Foucault 1991: 83)

This article addresses the way in which therapeutic practice in an English prison creates conditions whereby both prisoners and prison officers are caught up in networks and relationships of power that contribute to the constitution of particular subjects. The development of therapeutic practice, in relation to prisons and probation, is described and contextualised. Subsequently, the practices of group therapy in operation at Grendon prison - a rather unique institution built on principles of therapeutic community - are analysed with a focus on five "practices of moulding," namely, naming, confession, assessment and surveillance, tolerance and participation. The argument that psychotherapy, under conditions of imprisonment, is a form of repression or social control is discussed and dismissed as too simple a model to account for the relations of power and constitutive practices that effect all participants, not only prisoners. Members of staff, as well as prisoners, are shown to be caught up in the disciplinary web. Discipline, as opposed to control, is advocated as a more appropriate concept for understanding therapeutic practices in prison. The work of Thomas Mathiesen, on the concept of synoptic power, is introduced to help illustrate these dynamics. The article represents a shift in my own thinking, from scepticism to a pragmatic idealist position, that creates space for institutions like Grendon to be imagined as potential least worst options for people convicted of offences and obliged to serve "time". It is my hope, argued for in the article, that Grendon can be conceived of as a "visionary space" with emancipatory potential.

1 I am grateful to two anonymous reviewers for substantive critiques of earlier versions of this paper and to editor Morten Nissen for stimulating remarks that contributed to fine-tuning. Responsibility for ongoing limitations remains my own. I dedicate this article to John Beebe, ex-Grendon inmate, friend, and mentor in prison practices. 


\section{Background}

Psychotherapy and imprisonment would to most both liberal and conservative minded people appear to be mutually exclusive. The idea of a therapeutic prison would be anathema. This article draws on my own experience working for a short period at Grendon - a therapeutic prison in the $\mathrm{UK}$ - and my purpose is to show that both the liberal and the conservative positions are misguided. Whilst a conservative critique of a therapeutic prison would focus on the lack of necessity for therapy for obvious evildoers, the liberal critique would argue that therapy under structured constraints and apparent duress is merely a disguised form of state repression and therefore illegitimate ${ }^{2}$.

My original purpose with this article ${ }^{3}$ was in fact to articulate a liberal critique of Grendon prison, to show how the processes and practices of therapeutic communities are an extension of repressive social control. However, as I read McMahon's fine book The Persistent Prison and reread Michel Foucault's work on discipline I was presented with an alternative lens through which to analyse my own experiences and reflections on Grendon. To the degree that I began sceptically and end up advocating a more nuanced - what I call pragmatic idealist position - I in some way share common ground with Gender and Players, the authors of an in-depth study of Grendon, first published in 1995 three years after my 6 month stint at Grendon. They write

2 I am sympathetic to Nissen's persuasive critique (in Nordiske Udkast, 2002) of the liberal position where he demonstrates how control is always an aspect of care. A similar argument can be made about psychotherapy whether in prisons or elsewhere. There is always a normative element.

3 An earlier version was presented at the 28th Annual Conference of The European Group for the Study of Deviance and Social Control I am grateful to RCT and to Nordisk Samarbejdsråd for Kriminologi for financial support that enabled me to participate in this conference.
"We began with the view that a therapeutic prison was not a feasible proposition: that the demands of custody and treatment were antithetical." Yet, they continue, "we have been persuaded that a therapeutic prison is not only possible but desirable" (1995:17). The position I argue for in this article is not so much that therapeutic prisons are desirable, though one could draw that conclusion from my analysis, but that we must conceptualise the complexity of what goes on in the therapeutic prison in a manner that is less naive than the liberal and conservative critiques. The interesting issue for Gender and Players, (and myself) became not how "therapy could be used to exert control, but how such control differed from that enforced in other prisons and what purposes it served" (1995:17).

\section{A Caveat}

Gender and Players' study is rich in empirical material and illustrative cases, a result of their work being based on a clearly articulated research strategy. My own reflections are at a more general level of abstraction and at a greater distance from the material. This is a reflection of the fact that I was not conducting a specific study of Grendon whilst I was there. My own reflections are thus more experiential, ethnographic and in a sense post hoc. They are led by my analytic interest in exploring the relationship between care and control and also informed by the fact that at the time I worked at Grendon, I was living with an exGrendon inmate.

\section{Introduction}

Issues of power, both in practice and theory, in relation to psychological interventions have been of interest to me since I was first employed as a student in an English social work department working with so-called young offenders. These themes have pursued me throughout various jobs and various periods of study and remain pertinent in my current 
situation where I am connected to the research department of the Rehabilitation and Research Centre for Torture Victims (RCT).

This article focuses on the rise of the therapeutic in sites of control. The relationship between control and care, a relationship that comes into particular sharp relief in sites of control penetrated by therapeutic discourse, is problematised. The intention is to open up the practice of therapeutic discourse to deeper analysis, not necessarily to condemn it or praise it. I will describe the way forms of power in some sites of control have been transformed, alongside a consideration of what conditions have allowed for these changes (e.g. the psychologisation of everyday life).

Two key questions guide my analysis: Is therapeutic practice emancipatory (or liberative-McMahon 1992). Or is therapeutic practice a form of repression, a form of increased social control? In other words does therapeutic practice in prison create more humane conditions and offer opportunities that improve lives or does it close down opportunities and impose restrictive norms on thought and action? Or does it do something altogether different? These questions are rooted in the fundamental question: what do therapeutic practices do to people?

The idea that punishment following conviction for an offence is not merely a punishment or deterrent but also a correctional practice, a practice designed to produce reformed characters - to restore lost subjects - is not a new one. Both prisons and probation have been at different times perceived as more or less rehabilitative in their intention. Michel Foucault (1977: 123) has written, "the prison would constitute the "space between two worlds" the place for the individual transformation that would restore to the state the subject it had lost." The first world that the prison is between, is a lost world, a world alien, other, different to society, the inhabitation of which causes the delinquent's expulsion. The other world is the found world, the world outside the prison, that the delinquent discovers by finding himself in the correctional space of the prison.

Whilst attempts at rehabilitation have been public policy on and off throughout penal history, the application of psychology to people convicted of offences is a relatively recent phenomenon - let us say a late $20^{\text {th }}$ century phenomenon. This is of course a reflection of psychology's history and not much to do with the history of prisons. Only since the $2^{\text {nd }}$ World War did Therapeutic Communities (TC's) emerge as an approach to the treatment of those traumatised by war and it took some time before these all-encompassing models (first applied in a medical context) could be applied in a prison context. In the UK, Grendon Prison was first opened in 1962 and has for many years since stood as a single, largely ignored, flagship of therapeutic community principles applied in a carceral setting. Indeed, as Gender and Players put it "... for most of its 30 years of operation Grendon has inhabited an ideological wilderness, out of step with the prevailing ethos and marginal to mainstream penal practice" (Gender and Players, 1995:5). Therapeutic discourse is a late and marginal development in the history of dealing with people convicted of offences.

\section{Therapeutic discourse}

What do I mean by the term therapeutic discourse and practice? I do not just mean psychotherapy applied to individuals or groups. Nor do I merely mean the psy-disciplines (cf. Rose 1985). For me therapeutic discourse is much broader. Something therapeutic is something that brings about a change for the better in a person's psyche, being or lived world. Therapeutic discourse is a set of practices and ways of talking about changing a person for the better, more specifically about correcting or addressing a problem or set of problems. It is not just bodies, or workers that are targeted; it is selves who are subjected to a therapeutic 
intervention. In Foucault's terms it is lives and not just acts that are to be intervened upon. By using the term discourse I am attempting to avoid limiting the scope of the therapeutic to direct interventions by psy-professionals. Therapeutic discourse includes practices, programmes, politics and knowledge. It is a way of talking about persons convicted of offences as well as a way of writing about and acting towards or on them.

\section{Psychologisation}

Psychologisation is a term I use for recent developments in western liberal democracies that give pride of place to certain ways of viewing self and society, which can be seen as having to do with psychology. I mean, for example, the increase in references to ones self-esteem as a way of explaining why one is not successful; the way personal fulfilment has become a criteria for a good job; the way the unconscious has crept into popular discourse; to the other multiple ways in which psychological knowledge now pervades and informs many of the structures and institutions - courts, factories, schools, hospitals, prisons, families - which make up our societies. Psychological knowledge is a generous knowledge and it has not restricted itself to the academy. It has been adopted by the people. As Rose (1992:351) puts it "psychological know-how has made itself indispensable". This in turn makes possible "forms of expertise that have a particular capacity to graft themselves onto the practices of all those concerned with the conduct of conduct" (Rose, ibid.). Nikolas Rose has described variations on these themes in a number of places (e.g. Rose 1985, 1990, 1992, 1996) but an earlier more radical voice can be found in Castel, Castel and Lovell's social analysis of psychiatry in the USA (Castel et al, 1982). The authors describe contemporary social life as a psychiatric society describing how marginal groups are ordered and controlled through manipulative techniques borrowed from psychiatric discourse. Their interpretation of the psychologisation of everyday life is an example of the repressive hypothesis that I will challenge later, yet their description of developments in late $20^{\text {th }}$ century western societies is persuasive.

\section{Therapeutic discourse in sites of control}

Unlike Kyvsgaard (1997) who prescriptively, and naively in my view, concludes that treatment and punishment should be always separate (that treatment should be an opportunity and that it should occur under conditions of freedom) I take actual current practice as my starting point. Treatment is going on in sites of control ${ }^{4}$, that is, in prisons and in the community in the form of so-called community penalties. Prison and probation service programmes are sites of control in the sense that it is in them and under their jurisdiction that formal control is administered, that persons' freedom is restricted and certain obligations imposed. Below I will document what I call the rise of the therapeutic by referring to a number of programmes where people convicted of offences are subject not merely to a period of incarceration or supervision but to a therapeutic intervention. I begin by referring to therapeutic programmes in prisons and move on to consider therapeutic programmes for people convicted of offences, where the programmes are conducted outside the prison.

\section{Therapeutic discourse in prisons}

Grendon Prison established in 1962, as a therapeutic establishment, is structured and designed following the principles and practices of therapeutic community, which first came to

4 I will later problematise the designation of these programmes and practices, as sites of control, demonstrating how they should rather be designated sites of discipline. 
light, academically speaking, with the publication of a number of groundbreaking papers in $1946^{5}$, describing the ways in which psychiatric hospitals were being utilised in their wholeness as a therapeutic instrument. Some crucial ideas relating to these early communities are participation, social interactions, involvement, democratic organisational rule and the breaking down of barriers between doctor and patient. An irony about TC's within carceral institutions is that they are by definition levelling instruments, breaking down barriers between staff and clients and abandoning traditional hierarchies. Maxwell Jones (1968) stated "The TC concept involves a redistribution of power, authority and decision making ... and a more democratic egalitarian social structure generally". And Haddon described innovators of TC as trying "not to effect more humane control but to liberate." The aim was resocialisation into everyday life, that is, change, rehabilitation. In therapeutic communities the activities involved in the day to day running of the institution (be it hospital or prison) and the social relations which that unavoidably entails are the key to preparing the individual for a resocialised return to the outside world. TC's create subjects by involvement, participation, activity and talk. This model was to spread to other prisons during the 1990's.

In 1991-2, the former head of the Assessment Unit at Grendon established a therapeutic community unit at Gartree Prison in Leicestershire for 23 life sentence prisoners. The unit "is a multi-disciplinary staffed unit which aims to provide a safe environment within a prison setting in which prisoners can become reasonable, rational and responsible people through therapy" (association of therapeutic communities homepage, 2001a)

Praise for the Grendon model came from high places. In 1997, the Chief Inspector of Prisons stated: "I strongly support the work that is being done at Grendon, and the expansion of the therapeutic approach to other es- tablishments" (Ramsbotham 1997). Similarly, Richard Tilt, the Director General of the Prison Service is cited by Cullen (1998) as saying that Grendon "is a remarkable example of what can be achieved with the right approach and culture. I hope that we can recreate it somewhere before long". And in July 1997, the prison service announced that a new prison was to be built in Marchington, Staffordshire. This was to become the privately owned and run Dovegate prison. It currently has an operational capacity of 860 inmates. 200 of these places are in a therapeutic community regime set up following the Grendon model and opened on $12^{\text {th }}$ November 2001, 4 months after the main prison. This therapeutic regime is listed in the association of therapeutic communities' directory as a "residential TC for adult male prisoners ... with 4 years plus sentences." "Residents" must be over 21 years of age and the average stay is 18 months. The potential paradox of running a therapeutic community within a prison is captured in the answer to a question in this directory: "What is it about the organisation that makes it a Therapeutic Community?" Answer: "The entire TC section is run as a democratic TC within the contractual constraints of a prison" (see association of therapeutic communities homepage 2001b; H.M. prisons service homepage \& Prison Service press Release, July 1997).

Another Therapeutic Unit is the Max Glatt Unit in Wormwood Scrubs prison, which is primarily for sex offenders. Wexler (in Cullen, Jones \& Woodward $1997^{6}$ ) also reports surprisingly that 'TC's have recently become the treatment of choice in American prisons"(p161). This remarkable claim is related to an evaluation study of a programme

5 These were republished in The International Journal of Therapeutic Communities and Supportive Organisations 1996 Vol 17 No.2.

6 This text provides a fine overview of Therapeutic Community provisions for persons convicted of offences. 
on Staten Island, New York. This programme was specifically designed for offenders with substance abuse problems. Wexler states also that "the TC model was accepted as the most effective type of prison drug treatment intervention and was widely utilized in many states" (p.162). For example, in Texas in 1991 a treatment approach "provided prison inmates with 12 months of TC treatment followed by another 12 months of transitionary services in the community" (p163). Wexler describes these moves as a "shift in correctional policy emphasis from deterrence to rehabilitation" (p163). Losel (in Cullen, Jones and Woodward 1997) also describes the shift from "nothing works" based strategies towards what he describes as "correctional treatment". Losel's chapter is an introduction to the German social-therapeutic prisons whose development began in 1966. In 1994 Losel notes that 831 inmates were incarcerated in social therapeutic prisons. In 1997 there were " 15 social therapeutic settings and departments" in Germany.

The National Association for the Care and Rehabilitation of Offenders (NACRO, 1998) reported that the prison service runs Sex Offender Treatment Programmes (SOTP) in 25 UK prisons. The target for 1998-99 was for 680 prisoners to complete the programme. In response to a parliamentary question in the British House of Lords, Lord Williams of Mostyn stated that in the financial year 199899 "about 3000 prisoners are expected to complete accredited programmes" (Parliamentary Questions 19987 ). The accredited programmes referred to included SOTP and cognitive skills offending behaviour programmes (but not Grendon and the other TC oriented units).

7 The editor of Parliamentary Questions 1999 raises an interesting issue stating "Are SOTP's effective, or a placebo to allay public concern?" This question indicates the complex relation between the public and those imprisoned which informs policy making.

\section{Therapeutic discourse in the community}

NACRO (1998), in an article on the world wide web state "the number of treatment programmes for sex offenders run by the probation service has greatly increased in recent years." Statistics are cited from a 1995 survey by Chief Officers Of Probation showing that there were 109 community programmes for sex offenders with a capacity of 1907 places per year. The aim of these programmes was "to tackle and change (these) distorted attitudes." The Wolvercote Clinic is one example of a specialist residential treatment facility for sex offenders in the UK. Funding for residents comes partially from the Home Office if a client is referred by Probation and totally if referral is a condition of post-release supervision recommended by the parole board. Note here how treatment must be recognised as a condition for release, a requirement, an imposition. In an editors note to the reports of parliamentary questions on this issue an American article is cited which states that "approximately 1500 programs nationally provide some form of treatment for sex offenders", (Parliamentary Questions 1999).

At the Probation Centre where I was employed persons convicted of offences were assessed for suitability for a community sentence and programmes were developed and implemented where sentences would normally have been less than 2 years in prison. Assessments and recommendations for sentencing were submitted to the courts. Staff were mostly social workers and the programmes were constructed based on the assessed needs of referred persons often focussing on issues of housing, employment, and offending behaviour. The courts could choose to refer a person to a very specific group programme. 2 such programmes, both infused by therapeutic discourse were Anger Management and STARC Choices. STARC stands for STrategies Aimed 
at Reducing Crime and was a semi-structured group programme built around a cognitivebehavioural framework.

Anger Management, which I co-facilitated, was a programme that involved 12 weekly sessions of 2-3 hours. Participants were "sentenced" to attend the group knowing the alternative was probably prison. They were all men convicted of offences of violence including for example, assaults on partners and strangers, pub brawls and even road rage. For most it was not their first conviction for violence. The programme was semi-structured and certain topics such as drug and alcohol abuse, and effects on victims were addressed quite didactically but underlying practice was an assumption that facilitators were non-experts, that the group was participatory, that it was participants' own experiences and accounts of their own feelings, thoughts and behaviours which were important. We attempted to utilise Yalom's (1985) 12 therapeutic factors particularly interpersonal learning, instillation of hope, and universality. Official intentions of the group were to reduce offending behaviour. Facilitators assumed that one way to this goal was via critical self-reflection, by engagement with others, by the development of insight and by being challenged about one's actions.

\section{TC's in the wider penal context}

The above account of programmes, in and outside prisons, is far from exhaustive and serves merely to illustrate some developments in practices of dealing with people convicted of offences. It would be a mistake however to view the inroads therapeutic discourse has made in terms of programmes and practices as in any sense dominant. Therapeutic prisons are a minority. And the incursion of therapeutic practice is only one of a series of developments in penal practice in the last 30 years or so. Indeed even more recently one has begun to see the co-option of therapeutic discourse by a managerial ideology, where treatment pro- grammes become not about being humane or just, but about getting results quickly. Here it is not so much the rise of the therapeutic but the rise of a specific form of the therapeutic - the cognitive-behavioural paradigm. Even whilst I worked in probation I recognised in myself and colleagues what David Garland (2001) has called the "anomie" that professionals in so-called caring professions feel about the increasingly supervisory and control functions they are obliged to carry out in the name of efficiency and results. Indeed, penal policy and practice during the last decades has in my view been rather disturbing. Western prisons have become increasingly full, and law and order policies increasingly brutal and inhumane. David Garland (2001) in an important contribution to the study of contemporary penal practice and social change (in USA and UK), has listed 12 of the most important trends traceable during the last 30 years in this field. Three of these are particularly pertinent here, in order to contextualise the rise of the therapeutic. They are, the decline of the rehabilitative ideal, the re-emergence of punitive sanctions and expressive justice, and the reinvention of the prison. Regarding the latter Garland states, "the ruling assumption now is that "prison works" - not as a mechanism of reform or rehabilitation but as a means of incapacitation and punishment that satisfies popular political demands for public safety and harsh retribution" (14). And further, "In the course of a few decades it has gone from being a discredited and declining correctional institution into a massive and seemingly indispensable pillar of contemporary social order" (14). This then is the backdrop against which therapeutic discourse has simultaneously been making inroads. It is a rather paradoxical situation that points to the necessity of a serious consideration of alternatives to incarceration as incapacitation.

In this article I focus on the therapeutic prison, despite and because of its minority status. Perhaps there is a chance that such an analysis 
can contribute to presenting therapeutic prisons as a feasible alternative to the current harsh ideologies of punishment, retribution and expressive justice. The overview of programmes presented above is illustrative of the (limited) penetration of sites of control by the therapeutic, or more accurately of an alternative way of disciplining. Therapeutic discourse is not, in my view, a secret way of controlling deviants. Nor is it a straightforward liberative discourse. It is much more complex and the effects of power / knowledge associated with therapeutic discourse are much wider and further reaching. In order to illustrate this point I examine now the practices of moulding which I observed on the Assessment Unit (A Wing) of Grendon prison. I begin by introducing the structural and relational context in which these practices take place. Then I focus on the networks of relationships of power, the practices of moulding which effect both prisoners and prison officers and the types of subjectivity constituted by these networks, relationships and practices.

\section{The context}

\section{On arrival:}

\section{practices of investiture/divestiture ${ }^{8}$}

Certain rules apply to life on A Wing. When a new prisoner arrives he is expected to adopt these rules. The explicit ones, those laid down by the system, are simple enough to understand: no violence and no confidences. The premise behind the no-violence rule is to try to promote a safe, non-threatening, nonprison-like atmosphere. The premise behind the no-confidences rule is more deep-seated. It concerns the way the Grendon regime is all intrusive, all-pervading. Everything you say or do, or do not say or do not do, is part of the treatment, is analysable, is interpretable. Baron (1987) calls this the "ubiquity of interpretation." Prisoners are on the whole used to scrutiny, to strip searches, cell searches, searches of their visitors, but this total surveillance, this examination, probing at the very self of the inmate, is a new experience and of course something they are supposed to embrace.

\section{Small groups ${ }^{9}$}

The small group, meeting 3 times a week, is expected to absorb and welcome the hostile, fearful individual and gently mould them into an image suitable to get along in the therapeutic community. (Practices of "moulding" will be explored below.) In the small group, the inmate is expected to participate at his own pace to discuss and be reflective over his current fears, anxieties and expectations. Aims are clear and the organisational structure is explicit, but how individuals are "gently moulded" is not so clear.

\section{Community meetings}

Community meetings attended by all the inmates plus all available staff (who can be bothered to attend) are the focal point for community angst and conflict (resolution). Here, through practices of complaint, accusation, revelation, public reflection and feedback, democracy is established, denial challenged, responsibility assumed and underlined, and individuals made to feel accountable, both inmates and staff. This bullpen of testosterone is a place to be entered in fear and trembling, a place avoided perhaps understandably by staff members of a less therapeutically-minded nature. Here, rules are explored and enforced, votes taken and selves-in-community constituted. This is the crucible of organisational

8 Ashforth and Mael (1989:28) cite Van Maanen (1978) as using this terminology with reference to newcomer's identity in an organisational context. In this section I consider only a tiny part of the possible practices of investiture/divestiture which a newcomer to Grendon encounters.

9 See Gender and Players 1995:86-95 for additional detail illustrated with case examples, about the types of interaction that occur in small groups and wing meetings. 
transformation, the fire out of which the therapeutic instrument hopefully re-arises. Twice a week, in these meetings, the unit is informally reviewed and transformed in the process.

\section{Prison officer identity / function}

Prison officers on arriving at Grendon typically have an ambivalent / ambiguous set of expectations. The techniques of discipline and control taught in the prison training school can be seen in terms of managing the bodies of prisoners, managing time and space, and preparing for crises. But at Grendon staff are expected not only to lock and unlock doors but also to engage in therapeutic relationships. They are both "surveillers", holders of keys and "therapeutic instruments". They have the responsibilities for which they have been trained plus additional tasks of involving themselves with prisoners, participating in groups and observing and assessing prisoners' suitability for therapy.

I will consider a little later the product - that is, the particular kind of subjects - of the interconnections between the context, the relational network and the practices of moulding I observed.

\section{Prisoner identity / function}

When a prisoner arrives at Grendon it is assumed they wish to change, to examine their behaviour, their past, and to engage in a confessional process. They come ideally seeking a new identity. Men are seen as responsible agents both with respect to their crime and with respect to their potential for change. Some prisoners - not those at Grendon - see Grendon as a soft-option prison for "nonces and sickos" (child abusers and the mentally ill). Those prisoners motivated for therapy see it as the hardest part of their sentence, time spent examining themselves and being examined both by the system and by fellow prisoners, a time of learning to care for the self.

\section{Practices of moulding: an analysis}

As stated earlier the small group (and A Wing as a whole) is expected to absorb and welcome the hostile, fearful individual and gently mould him into an image suitable to get along in the therapeutic community. In this section I examine some of the practices that contribute to the moulding process, namely naming, confession, surveillance and assessment, tolerance, and participation. Moulding is not punishment that has a target and a clear result. Moulding is more of a subtle art, a sculpting, a re-forming.

\section{Naming}

Naming as a practice, as Strauss (1969) has noted, marks passage and acts to place or classify the individual. A practice peculiar to Grendon is the introduction of new members whereby everyone in a community meeting introduce themselves in the following manner: "I'm Jim doing 10 years for rape"; "I'm $\mathrm{Al}$, prison officer" Here one is positioned with respect to one's crime and one's sentence, and for staff one's difference (revealed also in uniform) is acknowledged. The brevity of staff announcements underlines perhaps that their "bird" (sentence) is limited to this 8 hour shift.

\section{Storytelling / Confession}

Whilst group meetings on A Wing are not primarily for therapy I consider them broadly speaking as therapeutic and of absolutely possessing a storytelling/confessional element. Rose and Foucault (Rose 1992) have both noted the parallel between the practice of therapy and the religious practice of confession. Rose writes specifically that confession has an identifying and a subjectifying character. By telling one's story within the confines of therapeutic discourse one's story is limited by that discourse and thus one's storied identity is 
also boundaried. Within the narrative perspective an interesting question is whether multiple stories can emerge or whether the prisoner is obliged to construct a single linear account of his life. It could well be that the practice of group therapy allows for the possibility of diverse accounts, that is, as one presents to a number of people over consecutive meetings a number of stories get told, contributing to a more nuanced and complex picture of the person. Olthuis (1994) has described a key part of the therapeutic process as getting the story straight, of ordering one's story such that it makes sense in the present. He has called this process re-story-ing, making a play on the verb restore, to make new. Story-telling as part of the therapeutic process is clearly a key player in the moulding of identity. One is moulded by one's own telling and by hearing the stories of others.

\section{Assessment \& surveillance}

The practice of assessment is, as mentioned with respect to the no-confidences rule, all-pervasive. It is not the psychological test which is paradigmatic here ${ }^{10}$, neither is it the concept of "test yourself". Rather it is a practice of "show yourself, reveal yourself" which predominates. The responsibility for being assessed positively, for being found suitable for therapy rests with the prisoner. Explicitly it is staff who assess. Yet they assess via observation. It is what they are presented with in everyday life on the wing that they have to assess. Thus the presentation of self in the best possible light is the goal of the prisoner. The prisoner must present an image to create an impression. Prison staff create an image based on their impressions. Presenting an image involves a constant selfreflection and self-surveillance.

10 Compare with Rose's (1992) account of psychological tests as paradigmatic of the (contemporary) era of the calculable individual.

11 Clegg (1998).
The practice of surveillance is an integral part of assessment. Yet there are no hidden cameras and the staff to prisoner ratio is not particularly high, whilst prisoners are relatively free to associate with whom they choose within the confines of the unit. Surveillance is again a form of self-control. Prisoners are constantly self-aware because of the practice of feedback whereby anything private or public can become material for discussion in small groups or wing meetings. Meetings can be seen as formalised, repetitive, ritualised events, similar to those focused on by Kilduff et al (1997), whereby prisoners have the opportunity to publicly display their image but also to reveal or disclose the images of others. Thus these two "mechanisms of power" surveillance ensure that the prisoner in Rose's words is "subjected not by an alien gaze but by a self-reflexive hermeneutic" (in Parker and Shotter 1990). Here we see "the operation of a relational power that sustains itself by its own mechanism and which for the spectacle of public events, substitutes the uninterrupted play of calculated gazes ... without recourse ... to excess, force or violence." (Foucault 1977:177) This is a "disciplinary power ... exercised through its invisibility; at the same time it imposes on those whom it subjects a principle of compulsory visibility" (Foucault 1977:187).

\section{Tolerance:}

\section{learning to accept self and other}

Prisoners must learn to practice tolerance. To be deemed suitable they must show they are responsible enough to hear others speak, able to give space, to be tolerant. Robbers must be able to demonstrate that they can tolerate child molesters and even listen to accounts of their crimes. Child molesters must dare to talk to robbers about their crimes. Dudiak (1998) has problematised the process of dialogue showing that dialogue is not sufficient for interparadigmatic communication. In the prison context 
how is it that sex offenders and robbers learn, or are expected to learn, to accept one another and grant each other legitimate rights in the community? The therapy manager's rationale is to place emphasis on sameness, to instil in the robber the idea that both parties are there to achieve change, that is they have shared goals. In addition they share a current life situation. The logic goes that it is harder to reject someone and easier to accept them the more similar they appear to me. But what happens to differences? Are they merely swept under the carpet? It would seem that by placing an emphasis on similarities the prisoner could be put at a disadvantage on entering the outside world where life is perhaps organised more along lines of differentiation than lines of similarity.

It could however be that what goes on is not so much an ignoring of difference - differences are after all reinforced regularly by the confession/naming ritual - but rather an emphasis instead on shared humanity and shared position. As Wenger (1998) would perhaps put it, engaging in shared activities gives rise to communities of practice where shared meanings are created which can potentially be inclusive if that is what is required for a given community to function.

Difference is not forgotten but perhaps the tenuous nature of members' attachment to the community allows simultaneously for identification and detachment ${ }^{12}$. To identify with the unit means to tolerate difference. The practice of collectively problematising the relationship between sex offenders and robbers (that is, the fact that this dynamic is constantly in the spotlight in community meetings) is perhaps a sign of the paradox of identity, that is, the simultaneous desires to belong and to be distinct. Staff must also learn to tolerate their charges. Commonality is also emphasised in this regard. Prisoners become persons in the

12 Meyerson and Kolb (1998) explore this possibility. eyes of staff through staff exposure to the raw existential facts of prisoners' lives that are revealed in groups. Combined with a need to live together, contact with prisoners' stories (their narrative identities) rather than with prisoners as number or crime statistic allows for a mutual experience of learning or getting to know one another.

In this way, through engaging in communities of practice, respective images and reputations become weakened and toleration, even acceptance, can be practised. Tolerance of others allows for tolerance of one's own "shadow" side and thus contributes to the moulding process.

\section{Participation}

On A Wing, to participate appropriately is to be on the road to be(com)ing more responsible. Participation can be viewed as transformative. One becomes something/someone new someone response-able, someone able to respond to one's fellow human beings in appropriate ways. If one does not participate, the ultimate danger is that one is returned to one's sending prison with lowered self-esteem and an experience of rejection in one's psychological baggage. One becomes something new anyway. The intervention, as any intervention, does make some difference. Change goes potentially either way. Wenger (1998) has described the dual-directional nature of communities of practice: they can function constitutively as both the "cradle of the self and the cage of the soul."

By participating (or not participating) one is created as a subject at the same time as one subjects oneself to the "psy practices" in which one actively engages. In this way one subjugates oneself; one actively allows oneself to be moulded, to be produced. And at the same time one produces a new community. As one is constituted, so one also constitutes. The types of subjectivity produced, feedback to the organisational context. The structural 
context of the day to day running of the unit is by definition changed by its very nature of being a "holder" or container for the constitution of identities. It does not determine but rather creates space for change and is changed by the spaces it creates, creating new spaces, new possibilities for forms of knowledge and networks of power.

Through the moulding of the organisation, through the debate, the speaking, and by the joint sense-making engaged in here, subjects are also further moulded. A circular process occurs: As prisoners are defining their lived-in context, they participate in their own subjectification. By redefining the collectivity, they redefine their own identity. What we can observe at Grendon is a parallel between talk of community identity and talk about issues of individual identity, that is to say the technologies of community development produce change in individual identity and vice versa.

\section{Panoptic and synoptic processes}

Mathiesen (1995 in Norwegian, 1997 in English), echoing Foucault, helpfully describes the shift from public execution to panoptic prisons as a shift from the many viewing the few to the few viewing the many. During public executions, townsfolk thronged in town squares en masse to witness the execution of a single person or a few people. In the panoptic model of prisons, a small number of staff are responsible for keeping an eye on the whole prison population. In the group therapy situation however, it is the few viewing the many and always also the many viewing the few. There is a two way process between staff facilitators and inmates whereby discipline crosses normal boundaries and implicates all participants. Whilst formal control looks like it goes from the few to the many, actual discipline, seen in actual practices goes all ways. I am in agreement with Mathiesen in his analysis of the dual roles the panoptic (the few see the many) and the synoptic (the many see the few) have in contemporary society. Later, I will discuss further panoptic and synoptic processes to show how it is discipline rather than control that is at work.

Above I have described 5 practices of moulding and touched on the panoptic and synoptic framing of interactions. I now consider briefly the relational network and the products of these relations and practices.

\section{The relations between staff and prisoners}

It is an implicit fact that the relational dynamics within the therapeutic community are the main source of therapeutic energy. The networks of relationships are rooted in the identities, positions and practices discussed above. In therapeutic community, both prisoners and staff have to reformulate their expectations of the institution, its members and their own positions within and in relation to it. The meeting of one self and another is recognised as a way of forming new identities.

\section{TC's as subjugating?}

Clare Baron (1987) argues that TC's are actually just as coercive and subjugating as more overt forms of control. She notes that the absence of formal rules can make informal rules all the more powerful. And she frames this as a critique. My question is why this should be framed in terms of a critique? She notes also a particular type of power - that of the power to make the rules within which games of power are played out. Whilst it is true that there is, in the prison setting, a framework within which relations of power/knowledge are located, this is not in fact created by prison staff as such. They do not make the rules. It is more structural and thus, I would argue, a more anonymous power. There are extreme tensions in the role played out by prison officers and they do have multiple functions. This does not necessarily make their function more coercive or make it inherently subjugating. It is rather a different form of power. It is a power which to use 
Foucault's terminology is both positive and productive. TC regimes are examples of the working of different kinds of power producing particular kinds of subjects.

\section{The product}

What is the product of the interconnections between the context, the relational network and the practices engaged in described in the previous sections? What kind of persons are produced?

Prisoners are assumed to be(come) responsible, choosing, self-observing subjects. Prison officers are assumed to be(come) accepting tolerant, empathic, open, psychologically aware in addition to being observers and enforcers of the rules. Both groups share, to a degree, the same community. Different forms of subjectivity are created. Different meanings are attributed via the different positions occupied and statuses acquired/given. TC's produce individual prisoners who can (maybe) function appropriately in society. TC's produce staff who can (maybe) adjust positions, cope with ambiguity, drop their status and participate alongside prisoners in the day to day running of the community.

\section{Discussion}

The above analysis makes clear that one-way models of relations of power/knowledge do not accurately represent the way things are in this particular type of regime.

Attempts to manage change in prisons have altered as certain prison regimes have undergone a shift from control to cure to care, paralleling a shift from punishment through treatment to therapeutic self-help ${ }^{13}$. At Grendon change is managed (if we can call it that) in/directly via expectation, by the setting of constraints and targets and by the establishment of local contexts where members engage in situated practice. Foucault (1977:172) wrote: "The old, simple schema of confinement and enclosure ... began to be replaced by the calculation of openings, of filled and empty spaces, passages and transparencies." Is this what we are seeing? Are we looking at an "indefinite discipline" as described in the following citation?

The ideal point of penality today would be an indefinite discipline: an interrogation without end, an investigation that would be extended without limit to a meticulous and ever more analytical observation, a judgement that would be at the same time the constitution of a file that was never closed, the calculated leniency of a penalty that would be interlaced with the ruthless curiosity of an examination, a procedure that would be at the same time the permanent measure of a gap in relation to an inaccessible norm and the asymptomatic movement that strives to meet an infinity. (Foucault 1977:227)

This seems accurate as a description of what I have analysed and yet I mistrust the negative tone. If this discipline actually targets all parties and the institutional apparatus, as I suggest, then it becomes less threatening, and less ominous than the above citation and the critical criminologists have claimed. It becomes less and not more ominous, given this picture, simply because staff do not have a monopoly on power. They are themselves caught up in power relations.

The therapeutic prison community is not a disciplining of subjects as much as it is a creation of space for the working of discipline itself. The management of change is not management in the sense of direct normative control, but the creation of opportunities, the constitution of necessary and sufficient conditions such that self-discipline can function in the modes non-specifically prescribed by the local, particular community. And self-disci-

13 As noted earlier, there is a danger that I overemphasise the rise of the therapeutic. If anything, given the present political dispensation, and much public opinion, at least in USA and UK, it is necessary to speak of a swing back to retributive justice and vengeance, at least when we think of penal practice more generally. 
pline includes staff too and the accountability of the institution.

The practices of moulding explored above are disciplinary practices. I make this claim despite McMahon's caveat: “Questions about whether specific penal practices should or should not be classified as "disciplinary" are interesting and difficult to answer" (McMahon 1992:34). Moulding practices are disciplinary practices in the sense that "discipline "makes" individuals; it is the specific technique of a power that regards individuals both as objects and as instruments of its exercise ... a modest, suspicious power, which functions as a calculated but permanent economy" (Foucault 1977:170).

\section{(Against) social control /}

\section{(For) discipline (as concepts)}

What are the implications of the above analysis of Grendon Prison for theories of social control? What does my analysis of disciplinary practices offer to debates in critical criminology? The arguments of social control theorists e.g. Scull (1984), Cohen \& Scull (1983) etc. have a lot to be said for them but I am sceptical about the broad theoretical approach they rest on, that is on the uni-directional exercise and action of control. McMahon (1992:211) expresses a degree of puzzlement over the way "Foucault's work has been more and more explicitly pertinent in the genesis of gloomy critical perspectives, particularly where corrections have been concerned." I too wonder why this is and whether it is a necessary reading of Foucault. McMahon implies that Foucault is misrepresented when she writes "therefore although power - following Foucault - is usually depicted as a creative or productive force, critical assessments of the exercise of power, and of its effects, are overwhelmingly negative." McMahon's major criticism of critical criminologists relates to their lack of reflexivity, lack of recognition of the function of their discourse in power/knowledge dy- namics: “... adequate study of penality must involve scrutiny of the contours of critical analysis" (ibid.1992:209). Analytically, the critical literature is problematic for focusing too deterministically on structures: "It denies the importance of human agency in the making of history" (ibid:45). Individual prisoners are not merely acted upon. They act back. Critical criminologists have claimed that the development of alternatives leads to an extension and expansion of the prison system itself - that is that they are not alternatives but additions: "In sum the critical literature on alternatives sees them not as simply different, but more intense, and more ominous, than earlier forms of control" (ibid:38) This is problematic for McMahon because "(T)he prospect it yields for praxis are pessimistic and conservative." (ibid.39) According to Ericson's foreword McMahon (ibid:xvi \& xxvii) criticises critical criminologists for their "one dimensional conception of power", and for "nihilism and an abstentionist political stance."

It is necessary to ask whether control is always and only negative? Should we not see control also as positive and productive? And, rather than condemning outright, attend instead to what is being produced by particular ideologies. Mathiesen (1994:ix) states that "The prison's function, according to Foucault, is among other things to create the criminal such that society can control him more easily" (my translation from the Norwegian). Whilst I agree with Foucault's claim that prisons make criminals, and thus define illegality and delinquency and also norms in society, I am not so sure that this is purposively with the intention of being able to "control them more easily." I am uneasy about the notion that there is a conscious activity on the part of the state that aims "to control more easily" a certain group of people (the delinquents). Foucault himself has negated readings of his work that accuse him either of neglecting the state or "imagining it capable of minutely controlling individuals' every- 
day lives" (1991:85). I question the notion of "control" understood as a one-way process, as power/knowledge administered and exercised by one group over another or by one individual in relation to another. For me there is no control of this kind. Mathiesen (1997:228, original in Norwegian 1995) defines control as "a change in behaviour or attitude in a wide sense, following from the influence of others". From where comes the influence? This definition implies an actor/agent but such a figure is not accounted for. Who controls and who is controlled? And I do not agree with Mathiesen that control and discipline are synonymous (ibid). For me, putting it rather aggressively, there is no control, only discipline. Discipline is the outworking of networks and relations of power/ knowledge which are unpredictable and work in all directions on all participants (and also on non-participants in that one cannot not be caught up in a web of power/knowledge.) Discipline seen in this way includes control but delimits and reduces its impact and effects at the same time as expanding and widening them.

My earlier analysis at the level of prisoners and prison staff reflects relations of power/knowledge in the wider sphere. That is, I believe relationships between liberal democratic societies and systems of justice within them can be analysed in similar ways. That is not to say the same disciplinary practices are going on but that the direction and effects of multiple discourses and the resultant web of power/knowledge is similarly multi-directional and complex. Power is not exercised over criminals without there being a counter-effect. Prisoners are not moulded without society being remoulded. All sides are in transition and all parties are implicated. Social control perspectives are not purely oppositional either. They participate in the wider discourse; they contribute to reform but by their very existence are also implicated in the status quo, in the maintenance and transformation of systems and practices of power/knowledge.
Do therapeutic practices of moulding retain elements of coercion? Is coercion inevitable in penal apparatus? Does coercion reach more widely in a therapeutic discourse than in a non-therapeutic discourse? The answer to this question is yes in the sense that disciplinary practices target the soul, yet this transformation or change itself brings with it other effects, non-prescribed, multi-directional effects which mitigate the coercive. Coercion, like power/ knowledge, is positive and productive. It is not just about making people do things they don't want to do.

Social control is seen as given by/in society. It is part and parcel of the relation between state and individual. Balvig (1999) writes: "The formal social control is taken as given. It is not that which we should formulate questions to or search answers for - or so we think". This last twist in the sentence is Balvig's way of undermining the givenness of social control (in Foucault's (1991:76) phrase, of “breaching the self-evident") and encouraging a radical questioning of so-called sites of control. Social control theories can tend to overestimate the power of institutions at the expense of more mundane practices, that is, there is a failure to analyse mundane disciplinary practices going on in the everyday lives of everyday people. My analysis of what actually goes on in a therapeutic prison and demonstration of effects in all directions makes this point.

What does it matter that therapeutic discourse targets the soul, social relations, ways of structuring self and other, one's sociality? The Chief Inspector of Prisons (Ramsbotham, 1997) recognises that the key factor in the Grendon approach is that "the community itself acts as the agent of change" (paragraph 13). This recognition is key to my understanding. It is not to say that persons are not responsible for their own change but that the community of which they are a part and in which they participate functions as a facilitator. When the community is a dynamic, in-transi- 
tion heterogenic unit, when the facilitator of change is as multiple and all encompassing as the TC regime is, its effects cannot be seen in simple terms of social control, expanding or otherwise.

\section{The dialectic between sites of control and society}

The conventional criminological wisdom of the 70's and 80's, regarding the relation between prison and society in terms of control, according to McMahon (1992:33) went as follows: "Analysts of decarceration portray the net effect of these trends as involving a dispersal of discipline: the prison retains its institutional strength and is interwoven with, and dependent on a "carceral continuum" that powerfully pervades social life in ever more subtle, complex and effective ways." In this wisdom the prison is seen as the "hard end of the system, with the boundaries between it and other control institutions becoming increasingly blurred. Community and private institutions - such as the family, school, neighbourhood and workplace - are seen as subject to "penetration" and "absorption" by formal modes of social control" (p.33; cf also Mathiesen 1997:228). It is perhaps easy to see how the critical criminologists read Foucault when one examines the next citation from Discipline and Punish:

There are two images then of discipline. At one extreme the discipline-blockade, the enclosed institution, established on the edges of society, turned inwards towards negative functions ... At the other extreme, with panopticism, is the discipline mechanism; a functional mechanism that must improve the exercise of power by making it lighter, more rapid, more effective, a design of subtle coercion for a society to come. The movement from one project to the other, from a schema of exceptional discipline to one of a generalised surveillance, rests on a historical transformation: the gradual extension of the mechanisms of discipline throughout the 17th and 18th centuries, their spread throughout the whole social body, the formation of what might be called in general the disciplinary society. (Foucault 1977:209)

I hope it is clear that I am much indebted to Foucault's work. However, it seems that I am running directly counter to a main thrust of Discipline and Punish, that the practices emerging in contemporary prisons then extended into society. I am, at least, suggesting a counter move whereby developments in society at large - in terms of the psychologisation of everyday life, the rise of the therapeutic - have extended backwards into criminal justice and prison systems. I do not doubt Foucault's proposition that illegality in society at large becomes defined in terms of those locked away and that prison is a particularly potent example of disciplinary mechanisms. I do doubt whether these mechanisms develop purely within the apparatus of the prison itself and then extend outwards. I propose a more dialectical, multi-directional approach which I believe is in keeping with the spirit of Foucault's writings. Foucault himself resists the idea of being a prophet, not least a prophet of doom. He is more about shaking up selfevident beliefs, of rocking and disrupting what we consider as taken for granted.

Above I have noted signs that the disciplinary society is taking revenge, sneaking back in to the discipline-blockade regimes and diluting and transforming them. I reject uni-directional models when it comes down to discussion of how and where did the therapeutic emerge. I think my above analysis of Grendon suggests a psychologisation of sites of control rather than a leaking over the wall of disciplinary practices developed in the prison. But this sneaking back in is not one way either. There is an exchange, a meeting of discourses and practices both within and without the prison walls. Like McMahon I see a dialectical process at work. Drawing on Foucault's Discipline and Punish McMahon (1992:5/6) claims, "For the last few centuries, the penal exercise of power and the generation 
of social-scientific knowledge have interacted with, and reinforced each other." Above I have described a variety of instances where therapeutic discourse has penetrated sites of control. Why do I use the word penetration? This implies therapy has impinged from outside of prisons, that it has broken in and is taking over. I do not actually believe this and it is misleading. McMahon (1992:8) refers to the "dialectical constitution and reproduction of dominant penal and social orders". Prisons are not separate from social life as a whole. Prison practices and other disciplinary practices both contribute to the psychologisation of everyday life and are an extension of it.

The boundaries between practices of discipline on people convicted of offences and wider society are permeable. The prison wall does not mark a boundary for the working of discipline. Discipline occurs everywhere; it cannot be limited by frontier posts or fences. It runs through, round and over all practices, policies and programmes.

\section{Conclusion: the therapeutic prison as "visionary space"}

... to portray Grendon purely as a mechanism of repressive state power, shrouded by a restrained medical imperialism, is to overlook an important humanitarian factor in the equation. The men who go to Grendon are typically in a state of distress: Grendon seeks to relieve their pain. (Gender and Players, 1995:14)

How does therapeutic discourse link to the traditional disciplinary/punitive functions of prisons? I have claimed it is not an extension of control nor a challenge to control but a transformation of forms of power. Many questions remain about these "new" forms of power.

At the beginning of this article I stated that my purpose was to show how the conservative and liberal critiques of the therapeutic prison are misguided. I am aware that I have mostly taken issue with the liberal critique.
This is primarily because I just do not accept the basic premise of the conservative postion that "crime is a decision, not a disease" as the former British Prime Minister John Major put it (quoted by Garland 2001, 198). Not that I believe crime to be a disease, but it is not only a personal decision. Crime must be understood within broader structural arrangements and social inequalities. Garland's text is insightful as he demonstrates how increasingly harsh crime control policies have been developed in parallel with increasingly anti-welfare social policies. Both sets of policies target the same social groups and as Garland (2001:201) puts it they "share the same assumptions, harbour the same anxieties, deploy the same stereotypes, and utilise the same recipes for the identification of risk and the allocation of blame". Crime is not so much a personal decision as a symptom of a social malaise. The other aspect of the conservative ideology I reject and the other reason for not wasting time trying to refute it, is that represented by the popular media, where offenders are seen as evildoers and monsters. The citation introducing this section indicates, as do my interactions with Grendon residents, that these inmates are distressed men requiring help. Assigning them stereotypical, even archetypal identities is no way to solve problems of crime. It is merely an abdication of responsibility.

My challenge to the liberal (or radical) critique and the repressive hypothesis is based on my analysis that the actual practice of the therapeutic prison is complex. There are structural forces in play, but the dynamics of power and discipline at work, for example in small groups and wing meetings, are slippery and multidirectional. All involved actors are implicated in the disciplinary web. My argument here draws on Mathiesen's insights about the importance of synoptic processes. In analysing the therapeutic prison, we need to take into account both the panoptic (social control) and the synoptic. The consequences 
of the synoptic (the many inmates viewing and engaging the few staff in a therapy session) are poorly understood. But recognition that staff are caught in such relations is necessary. Such recognition dilutes the power of the repressive hypothesis that therapy in prisons is necessarily subjugating and staff involved in therapy are merely agents of the state.

It is likely that I am overstating the case somewhat. Of course there are substantive differences between being a prisoner engaging in a therapeutic process and a member of staff. Nevertheless, I believe my analysis does challenge the liberal position (which, by the way, offers no alternative to the conservative hard line).

In my title I set a question mark against the idea of therapeutic discipline. I wondered whether the kind of discipline at work in regimes such as HM Prison Grendon could be therapeutic. I tend towards a hope (at least) that therapeutic discipline as analysed above is a more liberative punishment. McMahon (1992: 224) writes of how "while abolitionists have contributed greatly to critical understanding of the social reproduction of power relations through criminal justice discourses and practices, they have also sought to identify, appreciate and facilitate such visionary spaces and struggles as do exist." My hope is - and its a fragile and tentative one - that sites of therapeutic discipline might actually be "visionary spaces" and sites of genuine struggle both for prison staff and prisoners where change for the better both for individuals, organisational/relational structures and society might be facilitated. I further agree with McMahon (1992:218) that there is a need to discover and analyse "where, how and when ... have penal developments reflected elements of the "paradox of a liberative penality"?" This paper is offered as reflections on and a contribution to this paradox.

\section{References}

Ashforth, B.E. and Mael, F. (1989) "Social Identity and the Organisation", Academy of Management Review Vol. 14. 20-39.

Association of Therapeutic Communities homepage (2001a) http://www.therapeuticco mmunities.org/gtc.htm

Association of Therapeutic Communities (2001b) http://www.therapeuticcommunities.org/dirdovegate.htm;

Balvig, F. (1999) Kriminalitet og Social Kontrol, Copenhagen: Columbus.

Castel, F., Castel, R and Lovell, A. (1982) The Psychiatric Society, New York: Colombia University Press.

Cullen, E (1998) "Grendon and Future Therapeutic Communities in Prison", Prison Reform Trust http://penlex.org.uk/pages/prtgrend.html

Cullen, E,, Jones, L. and Woodward, R. (1997) Therapeutic Communities for Offenders, Chichester: John Wiley and Sons.

Cohen, S. and Scull, A. (1983) (eds.) Social control and the state: historical and comparative essays, Oxford: M. Robertson.

Dudiak, J. (1998) The Intrigue of Ethics: A Reading of the Idea of Discourse in the Thought of Emmanuel Levinas, Ph.d dissertation. Institute for Christian Studies, Toronto, Canada.

Foucault, M (1977) Discipline and Punish: the birth of the prison, New York: Random House.

Foucault,M. (1991) "Interview with Michel Foucault" in The Foucault Effect: Studies in Governmentality, Edited by G. Burchell, C. Gordon \& P. Miller., Chicago: University of Chicago Press.

Garland, D. (2001) The Culture of Control: crime and social order in contemporary society Chicago: University of Chicago Press.

Genders, E. and Player, E. (1995) Grendon: a study of a therapeutic prison, London: Clarendon Press.

H.M. Prison Service home page: http://www.hmp risonservice.gov.uk/prisons/default.asp

Jones, M. (1968) Beyond the therapeutic community; social learning and social psychiatry, New Haven: Yale University Press. 
Kilduff, M., Funk, J. \& Mehra, A. (1997) "Engineering Identity in a Japanese Factory", Organisation Science vol. 8. No. 6. 579-596.

Kyvsgaard, B. (1997) Den Kriminelle Karriere. Copenhagen: DJØF.

Mathiesen, T. (1994) "forord" in Overvågning og Straf by M. Foucault. Frederiksberg: Det Lille Forlag.

Mathiesen, T (1995) "I Michel Foucault's panopticon - en gjenvisitt", Retfard nr. 70.

Mathiesen, T (1997) “The Viewer Society. Michel Foucault's "Panopticon" revisited", Theoretical Criminology Vol 1, No.2, May 1997.

McKinlay, A and Starkey, K (eds.) (1998) Foucault, management and organisation theory: from panopticon to technologies of self, London: Sage.

McMahon, M. (1992) The Persistent Prison? Rethinking Decarceration and Reform, Toronto: University of Toronto Press.

Meyerson, D and Kolb, D. (1998) Ambivalence on the boundary: Identification within tenuous employment relationships, (Unpublished conference paper).

NACRO (September 1998) Sex Offenders: Reducing the Risk. http://www.penlex.org.uk/pages/ nacsxoff.html

Nissen, M. (2002) "Straf eller magt? En social kritik af "ungdomssanktionen", Nordiske Udkast Nr 12002 59-80.

Olthuis, J. (1994) "Being -with: Toward a Relational Psychotherapy", Journal of Psychology and Christianity 1994 vol.13, 217-331.

Olthuis, J (1997) Knowing other-wise: Philosophy at the threshold of spirituality, New York: Fordham University Press.

Parker and Shotter (1990) Deconstructing Social Psychology, London: Routledge.

Parliamentary Questions (December 1998) http: //penlex.org.uk/pages/pqoffbev.html

Parliamentary Questions (February 1999) http: //penlex.org.uk/pages/pqsotp.html

Press Release (Prison Service July 1997) New Prison Planned for Marchington http:// www.penlex.org.uk/pages/psn58.html

Ramsbotham, D. (H.M Chief Inspector Of Prisons)(Nov 1996) Short Inspection Report of Whitemoor Prison. http://www.penlex.org.uk/ pages/ciwhitem.html\#4.14
Ramsbotham, D. (H.M Chief Inspector Of Prisons)(Nov 1997.) H M Prisons Grendon and Springhill. Executive Summary of the full inspection report. http://www.penlex.org.uk/ pages/cigrend.html

Rose, N. (1985) The Psychological Complex: psychology, politics, and society in England, 18691939, London: Routledge \& Kegan Paul.

Rose, N. (1990) Governing the Soul: the shaping of the private self, London: Routledge.

Rose, N (1992) "Engineering the Human Soul: Analysing Psychological Expertise", Science in Context 5,2.

Rose, N. (1996) Inventing our selves: psychology, power, and personhood, Cambridge: Cambridge University Press.

Scull, A. (1984) Decarceration: community treatment and the deviant: a radical view, New Brunswick, N.J.: Rutgers University Press.

Strauss, A.L. (1969) Masks and Mirrors: the search for identity, Glencoe: Sociology Press.

Wenger, E. (1998) Communities of Practice: Learning, Meaning and Identity, Cambridge: Cambridge University Press.

Yalom, I. (1985, orig. 1970) Theory and Practice of Group Psychotherapy, New York: Basic Books. 